\title{
Korelasi Penerapan Penilaian Autentik Mata Pelajaran PAI Dan Budi Pekerti Dengan Prestasi Belajar Di SMAN 1 Simpang Rimba Kab. Bangka Selatan
}

\author{
Sutrisna ${ }^{1}$, Nasrun $^{2}$, Sumar $^{3}$ \\ 1IAIN Syaikh Abdurrahman Siddik \\ ${ }^{2}$ IAIN Syaikh Abdurrahman Siddik \\ ${ }^{3}$ IAIN Syaikh Abdurrahman Siddik
}

\section{Info Artikel :}

Diterima 22 Maret, 2020

Direvisi 20 April, 2020

Dipublikasikan 31 Mei 2020

\section{Kata Kunci:}

Korelasi

Penerapan

Penilaian autentik dan hasil belajar

\begin{abstract}
ABSTRAK
Fokus penelitian ini berkenan dengan korelasi penerapan penilaian autentik mata pelajaran PAI dan budi pekerti dengan prestasi belajar di SMAN 1 Simpang Rimba kab.Bangka Selatan. Tujuan penelitian ini adalah untuk mendeskripsikan korelasi penerapan penilaian autentik mata pelajaran PAI dan budi pekerti dengan prestasi belajar peserta didik di SMAN 1 Simpang Rimba Kab. Bangka Selatan. Jenis penelitian ini adalah penelitian kuantitatif, dengan menggunakan metode korelasi. Populasi dar ipenelitian ini adalah peserta didik kelas XI IIS I di SMAN 1 Simpang Rimba Kab.Bangka Selatan Tahun Ajaran 2018/2019 yang berjumlah 33 peserta didik. Dan sampel penelitian ini berjumlah 33 peserta didik. Teknik pengumpulan data penelitian ini menggunakan teknik angket dan dokumentasi. Teknik instrumen penelitian menggunakan uji validitas dan uji reliabilitas data. Teknik analisis menggunakan analisis korelasi. Uji hipotesis yaitu dapat membandingkan nilait hitung dengan nilai tabel. Setelah didapat inilait hitung sebesar2.076, berdasarkan data yang telahdipaparkan di atas, maka dapat disimpulkan bahwa thitung $>t_{\text {tabel }}$ dengan angka $2.076>1.697$, berarti $\mathrm{H}_{\mathrm{a}}$ diterima $\mathrm{H}_{0}$ ditolak. Namun bisa kita lihat bahwa hasil Correlations variabel $\mathrm{X}$ dan variabel Y. Nilai yang diperoleh sebesar 0,377 berarti terdapat hubungan yang rendah antar penilaian autentik dan prestasi belajar. Ini berarti bahwa korelasi penilaian autentik mata pelajaran PAI dan budi pekerti dengan prestasi belajar peserta didik di SMAN 1 Simpang Rimba Kab.Bangka Selatan menunjukan korelasi yang rendah.
\end{abstract}

\begin{abstract}
The focus of this study is pleased with the correlation between the application of authentic assessment of PAI subjects and manners with learning achievement at SMAN 1 Simpang Rimba, South Bangka Regency. The purpose of this study was to describe the correlation between the application of authentic assessment of PAI subjects and manners with student learning achievement at SMAN 1 Simpang Rimba Kab. South Bangka. This type of research is quantitative research, using the correlation method. The population of this study was students of class XI IIS I at SMAN 1 Simpang Rimba, South Bangka Regency, Academic Year 2018/2019, amounting to 33 students. And the sample of this study was 33 students. The data collection technique of this study used a questionnaire and documentation technique. The research instrument technique uses the validity test and the data reliability test. The analysis technique uses correlation analysis. Hypothesis testing that is can compare the calculated value with the value of ttable. After obtaining this count of 2,076, based on the data described above, it can be concluded that tcount> ttable with the number 2,076> 1,697, meaning Ha is accepted HO is rejected. But we can see that the results of the Correlations variable $X$ and $Y$ variables. The value obtained is 0, 377 means there is a low relationship between authentic assessment and learning achievement. This means that the correlation of authentic assessment of PAI subjects and manners with student achievement in SMAN 1 Simpang Rimba, South Bangka Regency shows a low correlation.
\end{abstract}




\section{PENDAHULUAN}

Zaman akan terus berubah dan berkembang, demikian halnya pendidikan. Hal ini dikarenakan pendidikan menyesuaikan dengan keadaan zaman, serta berbagai persoalan yang dihadapinya. Perlu adanya perubahan maupun pergantian kurikulum di Indonesia tentu tidak terlepas dari persoalan perubahan zaman. Sebab, hakikat penyelenggaraan pendidikan adalah untuk menjadi solusi terhdap persoalan-persoalan yang dihadapi bangsa dan negara. Dengan kata lain, melalui pendidikan bangsa dan negara ini akan mengalami kemajuan. Oleh karena itu, pendidikan perlu diselenggarakan secara optimal supaya menghasilkan lulusan-lulusan berkualitas yang memiliki kompetensi sikap, keterampilan, dan pengetahuan sesuai dengan standar nasional yang telah disepakati. ${ }^{1}$

Undang-Undang Nomor 20 Tahun 2003 tentang Sistem Pendidikan Nasional menyebutkan bahwa kurikulum adalah seperangkat rencana dan pengaturan mengenai tujuan, isi, dan bahan pelajaran serta cara yang digunakan sebagai pedoman penyelenggaraan kegiatan pembelajaran untuk mencapai tujuan pendidikan tertentu. Berdasarkan pengertian tersebut, ada dua dimensi kurikulum yang pertama adalah rencana dan pengaturan mengenai tujuan, isi, dan bahan pelajaran, sedangkan yang kedua adalah cara yang digunakan untuk kegiatan pembelajaran. ${ }^{2}$

Kurikulum merupakan sebuah wadah yang akan menentukan arah pendidikan. Berhasil dan tidaknya sebuah pendidikan sangat bergantung dengan kurikulum yang digunakan. Kurikulum adalah ujung tombak bagi terlaksananya kegiatan pendidikan. Tanpa adanya kurikulum mustahil pendidikan akan dapat berjalan dengan baik, efektif, efisien sesuai yang diharapkan. Karena itu, kurikulum sangat perlu untuk diperhatikan dimasing-masing satuan pendidikan. Sebab, kurikulum merupakan salah satu penentu keberhasilan pendidikan. Dalam konteks ini, kurikulum dimaknai sebagai serangkaian upaya untuk menggapai tujuan pendidikan. Pendidikan merupakan upaya untuk mencerdaskan kehidupan bangsa dan meningkatkan kualitas pengetahuan peserta didik sesuai dengan harapan kurikulum pendidikan.

Kurikulum pendidikan senantiasa bersifat dinamis, menyesuaikan diri dengan berbagai keadaan supaya dapat memantapkan pembelajaran dan hasil belajar. Dengan demikian harus diadakan perubahan kurikulum pendidikan sampai saat ini terjadi nya perubahan kurikulum. ${ }^{3}$ Banyak masyarakat berasumsi bahwasannya setiap pergantian menteri pendidikan maka kurikulum pendidikan juga akan berganti. Dengan demikian kurikulum harus bisa menjawab kebutuhan masyarakat dalam menghadapi persoalan kehidupan yang dihadapi. Hal ini membuat perkembangan kurikulum senantiasa mengikuti perkembangan zaman. Peran kurikulum sangat penting dalam membentuk karakter peserta didik baik di lingkungan sekolah maupun luar sekolah serta dapat meningkatkan prestasi belajar. Prestasi belajar yang memuaskan dapat diperoleh apabila kegiatan belajar dan pembelajaran yang dilakukan oleh pendidik berhasil dengan baik, cepat dan tepat. Namun pembelajaran yang baik tidak akan tercapai tanpa faktorfaktor pendukung yang memadai. ${ }^{4}$

Selain faktor pendukung yang memadai dalam meningkatkan prestasi belajar maka ada penilaian yang harus diterapkan oleh seorang guru. Sesuai dengan tuntutatn Kurikulum 2013 maka penilaian yang diterapkan adalah penilaian autentik. Penilaian autentik meliputi aspek kognitif, afektif, dan psikomotorik. Namun penilaian masih banyak kendala yang dilakukan oleh guru-guru terutama kesulitan dalam penerapan penilaian autentik.

Berdasarkan wawancara sementara dengan guru-guru ternyata masih kesulitan dalam penerapan penilaian autentik itu sendiri ketika proses pembelajaran berlangsung. Seharusnya berdasarkan tuntutan Kurikulum 2013 guru wajib menggunakan penilaian autentik. Namun kendala nya masih saja guru kurang memahami penilaian autentik dalam penerapan Kurikulum 2013. Pendidik bukan hanya mengalami kesulitan pada saat proses pembelajaran namun pada sistem penilaian juga.

Berkaitan dengan penjelasan di atas bahwa SMAN 1 Simpang Rimba salah satu sekolah yang ada di Bangka Selatan yang sudah menerapkan Kurikulum 2013 sesuai dengan tuntutan kurikulum yang berlaku. Sebagai mana yang terjadi di SMAN 1 Simpang Rimba guru-guru sudah menerapkan penilaian autentik namun masih saja ada kendala dalam penilaian tersebut. Bukan hanya pengetahuan saja yang harus dinilai melainkan sikap dan keterampilan harus dinilai juga. Dengan adanya penilaian sikap, pengetahuan dan keterampilan guru harus senantiasa memahami cara penilaian yang berlaku sesuai

\footnotetext{
${ }^{1}$ M. Fadlillah, Implementasi Kurikulum 2013 dalam Pembelajaran SD/MI, SMP/MTs, \& SMA/MA, (2014):17.

2 Permendikbud No. 69 Tahun 2013 tentang Kerangka Dasar dan Struktur Kurikulum Sekolah Menengah Atas / Madrasah Aliyah

3 Kunandar, Guru Profesional Implementasi Kurikulum Tingkat Satuan Pendidikan (KTSP) dan Sukses dalam Sertifikasi Guru, (2010):107

${ }^{4}$ Muhammad Fathurrohman dan Sulistyorini, Belajar \& Pembelajaran Meningkatkan Mutu Pembelajaran Sesuai Standar Nasional, (2012):4.
} 
dengan tuntutan Kurikulum 2013. Dengan demikian ketika penilaian sikap, pengetahuan dan keterampilan dilaksanakan dengan baik maka proses pembelajaran akan berdampak dengan peningkatan presetasi belajar peserta didik. Namun sebaliknya ketika penilaian sikap, pengetahuan dan keterampilan tidak dilaksanakan dengan baik maka akan berdampak dengan penurunan prestasi belajar peserta didik.

Berdasarkan pembahasan di atas, makapeneliti ingin melihat sejauh mana korelasi penilaian autentik yang dilakukan oleh guru PAI dan budi pekerti meningkatkan prestasi belajar peserta didik. Sehingga dalam hal ini peneliti tertarik untuk meneliti kelas XI IIS I tentang "Korelasi Penerapan Penilaian Autentik Mata Pelajaran PAI Dan Budi Pekerti Dengan Prestasi Belajar Peserta Didik di SMAN 1 Simpang Rimba Kab. Bangka Selatan".

Untuk memudahkan dalam proses penelitian ini, penelitian membuat rumusan masalah ini sebagai berikut:Apakah terdapat korelasi antara penerapan penilaian autentik mata pelajaran PAI dan budi pekerti dengan prestasi belajar peserta didik di SMAN 1 Simpang Rimba Kab. Bangka Selatan?

\section{METODE}

Jenis penelitian ini adalah penelitian kuantitatif yang lebih menekankan pada pengumpulan data berupa angka dan menggunakan analisis statistik sebagai dasar dalam pemaparan data dengan memakai metode survei (survey research), yaitu penelitian dengan mengambil sampel dari populasi dan angket sebagai pengumpul data pokok. Penelitian kuantitatif dapat diartikan sebagai metode penelitian yang digunakan untuk meneliti pada populasi atau sampel tertentu, pengumpulan data menggunakan instrumen penelitian, analisis data bersifat kuantitaif, statistik, dengan tujuan menguji hipotesis yang telah ditetapkan. ${ }^{5}$

Dalam penelitian ini penulis bermaksud meneliti korelasi penerapan penilaian autentik mata pelajaran PAI dan budi pekerti dengan prestasi belajar peserta didik kelas XI IIS 1 SMAN 1 Simpang Rimba Kabupaten Bangka Selatan. Penelitian ini meliputi 2 variabel yaitu Penerapan Penilaian Autentik (X), dan Prestasi Belajar (Y). Penelitian ini dilakukan di SMAN 1 Simpang Rimba yang berlokasi di jalan Batin Tikal Simpang Rimba, Kec. Simpang Rimba, Kab. Bangka Selatan, Provinsi Kepulauan Bangka Belitung. Waktu yang digunakan dalam penelitian yang berjudul "Korelasi Penerapan Penilaian Autentik Mata Pelajaran PAI dan Budi Pekerti dengan Prestasi Belajar Peserta Didik di SMAN 1 Simpang Rimba Kab. Bangka Selatan", terhitung dimulai sejak surat izin penelitian yang dikeluarkan oleh Institut Agama Islam Negeri Syaikh Abdurrahman Siddik Bangka Belitung Nomor: 01211 Tahun 2018. Populasi dalam penelitian ini, yaitu seluruh peserta didik kelas XI IIS I di SMA Negeri 1 Simpang Rimba Kab. Bangka Selatan yaitu berjumlah 33 peserta didik.

Tabel I. 2

Jumlah Populasi

\begin{tabular}{|c|c|c|}
\hline No & Kelas & Jumlah \\
\hline 1 & IIS 1 & 33 \\
\hline
\end{tabular}

Sumber data: dokumentasi SMAN 1 Simpang Rimba Kab. Bangka Selatan

Untuk itu sampel yang diambil dari populasi harus betul-betul represntatif (mewakili). Dalam penelitian ini jumlah relatif kecil dan kurang dari 100, maka peneliti mengambil semuanya untuk dijadikan sampel, berjumlah 33 orang. Berhubungan dengan jumlah populasi yang menjadi perhatian peneliti berjumlah kurang dari 100 maka keseluruhan populasi tersebut diambil sebagai sampel dalam penelitian ini.

Adapun sumber data yang dipergunakan dalam penelitian ini adalah:

Dalam penelitian ini sumber data pertama adalah skala pengukuran penerapan penilaian autentik dan skala raport peserta didik. Dalam penelitian ini yang dijadikan data sekunder adalah dokumentasi yang berasal dari SMAN 1 Simpang Rimba Kab. Bangka Selatan.

\section{Teknik Pengumpulan Data}

Angket sebagai instrumen pengumpulan data dibuat untuk memperoleh informasi yang relevan dengan tujuan penelitian. Dalam penelitian ini menggunakan angket tertutup. Dalam memperoleh informasi dari objek yang diteliti peneliti menggunakan cara seperti memberikan sejumalah pertanyaan tertulis dalam bentuk butir soal pilihan ganda yang diberi skor dalam tiap butir soal yang digunakan untuk memperoleh informasi dari responden ${ }^{6}$. Pertanyaan dalam angket berhubungan dengan indikatorindikator penilaian autentik dan prestasi belajar peserta didik.Angket/kuesioner berisi beberapa

\footnotetext{
${ }^{5}$ Burhan Bungin, Metodologi Penelitian Kuantitatif: Komunikasi Ekonomi Kebijakan Publik Serta Ilmu-Ilmu Sosial Lainnya, (2013): 132.

${ }^{6}$ Riduwan, Skala Pengukur Variabel-Variabel Penelitian, (2007):25
} 
pernyataan tentang penilaian autentik yang berjumlah 20 item dalam bentuk checklist dengan empat pilihan jawaban yang harus dipilih peserta didik. Pedoman penskoran menggunakan skala likert yaitu, Selalu (4), Sering (3), Kadang-kadang (2), Tidak Pernah (1).

\section{Dokumentasi}

Dokumentasi adalah suatu metode yang dipergunakan peneliti untuk mengumpulkan data yang hanya ada pada catatan-catatan, buku, dan sebagainya. Metode ini dilakukan untuk mencari dokumendokumen yang dianggap penting dan relevan dengan yang diteliti. Diantaranya meliputi data daftar nama guru, peserta didik, serta karyawan di SMAN 1 Simpang Rimba Kab. Bangka Selatan.

\section{Teknik Instrumen Penelitian}

\section{Uji Validitas Instrumen}

Validitas adalah suatu derajat ketepatan instrumen (alat, ukur), maksudnya apakah instrumen yang digunakan betul-betul tepat untuk mengukur apa yang akan diukur. ${ }^{7}$ Setelah data didapat dan ditabulasikan, maka penguji validitas konstruksi dilakukan dengan analisis faktor yaitu dengan mengkorelasikan antara skor item instrumen dengan rumus CorrelationPearson Product Moment sebagai berikut:

$$
\text { rhitung }=
$$

Keterangan:

$r_{\text {hitung }}=$ Kofisien Korelasi

= Jumlah skor item

$=$ Jumlah skor total

n = Jumlah Responden

Selanjtnya dihitung menggunakan Uji-t dengan rumus:

thitung

keterangan:

$\mathrm{t}=$ Nilai $\mathrm{thitung}$

$\mathrm{r}=$ Koefidien korelasi hasil rhitung

$\mathrm{n}=$ Jumlah responden

Adapun distribusi (Tabel t) untuk dan derajad keabsahan ( $d k=n-2)$. Sedangkan kaidah keputusan: jika $r_{\text {hitung }}>\mathrm{r}_{\text {tabel }}$ berarti valid, sebaliknya jika $\mathrm{r}_{\text {hitung }}<\mathrm{r}_{\text {tabel }}$ berarti tidak valid. Jika instrumen itu valid, maka dilihat kriteria penafsiran mengenai indeks korelasinya ( $\mathrm{r}$ ) sebagai berikut:

Antara 0,800 sampai dengan 1,000 : sangat tinggi

Antara 0,600 sampai dengan 0,799 : tinggi

Antara 0,400 sampai dengan 0,599: cukup tinggi

Antara 0,200 sampai dengan 0,399: rendah

Antara 0,000 sampai dengan 0,199 : sangat rendah (tidak valid).

Berdasarkan hasil angket variabel X sebanyak 20 item pernyataan semua valid. Untuk lebih jelasnya data ini dilampirankan.

\section{Uji Reliabilitas Instrumen}

Suatu instrumen pengukuran dikatakan sahih jika pengukurannya konsisten, cermat, dan akurat dengan tujuan utama untuk mengetahui konsistensi dari instrumen sebagai alat ukur, sehingga hasil suatu pengukuran dapat dipercaya. Untuk menguji reliabilitas angket dalam penelitian ini digunakan rumus Spearman Borwn (Split Half) antara lain:

$r_{\mathrm{i}}$

$r_{\mathrm{i}}$

$\Sigma \sigma_{b}{ }^{2}$

$\sigma_{\mathrm{t}}^{2}$
$=$

= Reliabilitas instrumen

= Banyaknya butir pertanyaan atau banyaknya soal

= Jumlah varians butir

= Varian total

Reliabilitas dari dua variabel X dan Y hasil instrumen peneliti dinyatakan reliabel atau konsisten. Karena hasil perhitungan variabel X dan Y reliabilitas instrumen peneliti lebih tinggi dari $r_{\text {tabel }}(0,374)$. Untuk lebih jelasnya data dilampirkan.

\section{Teknik Analisis Data}

\section{Analisis Korelasi}

Analisis korelasi dilakukan untuk mengetahui kuat lemahnya hubungan antar variabel yang dianalisis. Menjawab pertanyaan penelitian nomor satu, yaitu apakah terdapat korelasi antara penerapan penilaian autentik dengan prestasi belajar peserta didik.

\footnotetext{
7 Sugihartono, dkk, Psikologi Pendidikan, (2007):19.
} 
Data yang diperlukan untuk penelitian ini terkumpul, maka akan diolah melalui berbagai tahap seperti: editing, koding, skoring. Kemudian dilakukan pentabulasian data untuk memudahkan penganalisaannya. Kemudian data tersebut dianalisis data dengan menggunakan teknik analisis data kuantitatif dengan uji statistik.

Langkah selanjutnya yaitu, menganalisa data. Analisis data dimaksudkan agar mudah untuk pengujian hipotesis dan menjawab rumusan masalah yang diajukan dengan skala interval dan ratio. Dalam analisis data ini, penulis menggunakan uji Reliabilitas Instrumen dengan menggunakan SPSS 17.0 atau menggunakan rumus Correlation Pearson Product Moment. Adapun rumus Correlation Pearson Product Moment dengan teknik belah dua awal-akhir yaitu:

Correlation Pearson Product Moment dilambangkan (r) dengan ketentuan nilai $r$ tidak lebih dari harga ($1<\mathrm{r}<+1$ ). Apabila nilai $\mathrm{r}=-1$ artinya korelasinya negatif sempurna : $\mathrm{r}=0$ artinya tidak ada korelasi : dan $r=1$ berarti korelasinya sangat kuat. Maka, antara Variabel X dan Variabel Y memiliki hubungan yang sangat kuat.

\section{HASIL DAN PEMBAHASAN}

\section{Deskripsi Data Penelitian}

Untuk menjawab rumusan masalah yang telah diajukan, yakni mengetahui apakah ada korelasi penerapan penilaian autentik mata pelajaran PAI dan budi pekerti dengan prestasi belajar di SMAN 1 Simpang Rimba Kab. Bangka Selatan. Maka langkah pertama yang dilakukan adalah dengan memberikan item angket dari variabel dependen dan independen yang telah diuji validitas dan reliabilitas kepada guru di SMA Negeri 1 Simpang Rimba Kab. Bangka Selatan. Untuk penilaian autentik terdiri dari 20 item soal yang diisi oleh guru yang terdiri dari 28 orang.

Untuk variabel dalam penelitian ini, masing-masing item angket diberikan skor jika pilihan jawabannya (SL) diberi nilai 4, pilihan jawaban (S) diberi nilai 3, pilihan jawaban (KD) diberi nilai 2, dan pilihan jawaban (TP) diberi nilai 1. Setelah data tersebut diperoleh barulah data diolah kemudian mendapatkan nilai yg diperlukan. Adapun hasil deskriptif data responden penilaian autentik (X) dan prestasi belajar (Y) dilakukan dengan menggunkan bantuan program SPSS versi 17.0.

Tabel IV.1

Data responden antar variabel Penilaian Autentik dan Prestasi Belajar

\begin{tabular}{|l|l|r|r|}
\hline & & $\begin{array}{c}\text { Penilaian } \\
\text { Autentik }\end{array}$ & Prestasi Belajar \\
\hline \multirow{2}{*}{ N } & Valid & 28 & 33 \\
\cline { 2 - 4 } & Missing & 5 & 0 \\
\hline Mean & 62.57 & 80.58 \\
\hline Median & 60.50 & 80.00 \\
\hline Mode & 50 & 80 \\
\hline Std. Deviation & 9.065 & 3.298 \\
\hline Variance & 82.180 & 10.877 \\
\hline Range & 32 & 20 \\
\hline Minimum & 48 & 70 \\
\hline Maximum & 80 & 90 \\
\hline Sum & 1752 & 2659 \\
\hline
\end{tabular}

Variabel Penilaian Autentik (X)

Hasil data dari 28 orang responden diperoleh hasil untuk rata-rata (Mean) sebesar 62.57; titik tengah $($ Median $)=60.50$; nilai yang sering muncul $($ Mode $)=50 ;$ simpangan baku $($ Standar Deviasi $)=9.065$; tingkat penyebaran data (Variance) $=82.180$; rentangan $($ Range $)=32$; skor minimum $($ Min) terdapat pada angka 48 dan skor maksimum (Max) pada angka 80; sedangkan jumlah skor keseluruhan (Sum) sebesar 1.752 .

Variabel Prestasi Belajar (Y)

Hasil data dari 33 orang responden diperoleh hasil untuk rata-rata (Mean) sebesar 80.58; titik tengah $($ Median $)=80.00$; nilai yang sering muncul $($ Mode $)=80 ;$ simpangan baku $($ Standar Deviasi $)=3.298$; 
tingkat penyebaran data $($ Variance $)=10.877$; rentangan $($ Range $)=20$; skor minimum $($ Min $)$ terdapat pada angka 70 dan skor maksimum (Max) pada angka 90; sedangkan jumlah skor keseluruhan (Sum) sebesar 2.659.

\section{Uji Persyaratan Analisis}

Sebelum melakukan uji hipotesis dengan menggunakan teknik analisis pearson product moment, maka asumsi-asumsi yang melandasi penggunaan teknik analisis tersebut harus diuji terlebih dahulu, hal itu dilakukan untuk mendasari tingkat kepercayaan pengambilan kesimpulan, yang mana teknik ini dapat diterapkan apabila asumsi yang melandasi penggunaanya terpenuhi. Uji persyaratan analisis tersebut meliputi:

\section{Uji Normalitas Data}

Uji normalitas data digunakan untuk mengetahui normal tidaknya suatu data. Data dinyatakan berdistribusi normal jika signifikansi lebih besar dari 0,05. Adapun untuk uji nomalitas data antar data responden variabel Penilaian Autentik (X) dan Prestasi Belajar (Y) menggunakan SPSS versi 17.0.

Tabel IV.2

Tests ofNormality

\begin{tabular}{|l|r|r|r|l|r|r|}
\hline & \multicolumn{3}{|c|}{$\begin{array}{c}\text { Kolmogorov- } \\
\text { Smirnova }\end{array}$} & \multicolumn{4}{c|}{ Shapiro-Wilk } \\
\hline & Statistic & df & Sig. & Statistic & Df & Sig. \\
\hline Penilaian Autentik & .140 & 28 & $\mathbf{1 6 8}$ & .935 & 28 & .082 \\
\hline Prestasi Belajar & .156 & 28 &. $\mathbf{0 8 0}$ & .936 & 28 & .088 \\
\hline
\end{tabular}

\section{Lilliefors Significance Correction}

Dari data di atas dapat dilihat pada kolom Kolmogorov-Smirnova dan dapat diketahui bahwa nilai signifikansi untuk variabel Penilaian Autentik sebesar 0,168 dan Prestasi Belajar sebesar 0,080. Karena signifikansi untuk kedua variabel lebih besar dari 0,05, maka dapat disimpulkan bahwa kedua variabel berdistribusi Normal.

Pada output SPSS versi 17.0 terdapat dua jenis hasil perhitungan yaitu Kolmogorov-Smirnovadan ShapiroWilk. Kriteria pengujian normalitas menurut kedua versi ini, jika p value Sig> 0.05. Nilai pvalue Sig merupakan nilai perhitungan hasil pengujian normalitas. Terdapat beberapa istilah dalam tabel output SPSS tersebut, istilah statistic menunjukan nilai Df yaitu jumlah data. Sig, adalah pengujian nilai probabilitas.

\section{Uji Analisis Korelasi}

Untuk mengetahui korelasi penilaian autentik mata pelajaran PAI dan budi pekerti denganprestasi belajar peserta didik di SMAN 1 Simpang Rimba Kab. Bangka Selatan, penulis melakukan analisis korelasi dengan menggunakan program SPSS versi 17.0.

Tabel IV.3

Correlations

\begin{tabular}{|l|l|r|r|}
\hline & & $\begin{array}{c}\text { Prestasi } \\
\text { Belajar }\end{array}$ & $\begin{array}{c}\text { Penilaian } \\
\text { Autentik }\end{array}$ \\
\hline \multirow{2}{*}{$\begin{array}{l}\text { Pearson } \\
\text { Correlation }\end{array}$} & $\begin{array}{l}\text { Prestasi } \\
\text { Belajar }\end{array}$ & 1.000 & .377 \\
\cline { 2 - 4 } & $\begin{array}{l}\text { Penilaian } \\
\text { Autentik }\end{array}$ & .377 & 1.000 \\
\hline \multirow{2}{*}{ Sig. (1-tailed) } & $\begin{array}{l}\text { Prestasi } \\
\text { Belajar }\end{array}$ & & .024 \\
\cline { 2 - 4 } & $\begin{array}{l}\text { Penilaian } \\
\text { Autentik }\end{array}$ & .024 & \\
\hline N & $\begin{array}{l}\text { Prestasi } \\
\text { Belajar }\end{array}$ & 28 & \\
\cline { 2 - 4 } & $\begin{array}{l}\text { Penilaian } \\
\text { Autentik }\end{array}$ & 28 & \\
\hline
\end{tabular}

Bisa kita lihat bahwa hasil Correlations variabel X dan variabel Y. Nilai yang diperoleh sebesar 0,377 berarti terdapat hubungan yangrendah antar penilaian autentik dan prestasi belajar. Ini berarti 
bahwa korelasi penilaian autentik mata pelajaran PAI dan budi pekerti dengan prestasi belajar peserta didik di SMAN 1 Simpang Rimba Kab. Bangka Selatan menunjukan korelasi yang rendah.

Untuk dapat memberi interpretasi terhadap kuatnya hubungan tersebut maka digunakan pedoman seperti yang tertera pada tabel berikut:

Tabel IV.4

Interpretasi Koefisiensi korelasi

\begin{tabular}{|c|c|}
\hline Interval Koefisien & Kekuatan Hubungan \\
\hline $0,000-0,199$ & Sangat Rendah \\
\hline $0,200-0,399$ & Rendah \\
\hline $0,400-0,599$ & Cukup Tinggi \\
\hline $0,600-0,799$ & Tinggi \\
\hline $0,800-1,000$ & Sangat Tinggi \\
\hline
\end{tabular}

Dapat pula dengan cara memanggil ulang data tabel koefisien seperti tabel di bawah ini:

Tabel IV.5

Coeffientsa $^{a}$

\begin{tabular}{|c|c|c|c|c|c|c|}
\hline \multirow[b]{2}{*}{ Model } & & \multicolumn{2}{|c|}{$\begin{array}{c}\text { Unstandardized } \\
\text { Coefficients }\end{array}$} & \multirow{2}{*}{\begin{tabular}{|c|}
$\begin{array}{c}\text { Standardized } \\
\text { Coefficients }\end{array}$ \\
Beta \\
\end{tabular}} & \multirow[b]{2}{*}{$\mathbf{T}$} & \multirow[b]{2}{*}{ Sig. } \\
\hline & & B & \begin{tabular}{|c|} 
Std. \\
Error
\end{tabular} & & & \\
\hline \multirow[t]{2}{*}{1} & (Constant) & 92.764 & 5.741 & & 16.157 & .000 \\
\hline & $\begin{array}{c}\text { Penilaian } \\
\text { Autentik }\end{array}$ & -.189 & .091 & .377 & 2.076 & .048 \\
\hline
\end{tabular}

Pada tabel Coeffcientsa ${ }^{a}$ didapat nilai thitung yaitu 2.076. Kemudian nilai $t_{\text {tabel }}$ untuk jumlah responden 33 orang 1.697 (lihat pada lampiran). Setelah kedua nilai t diketahui, selanjutnya membandingkan nilai

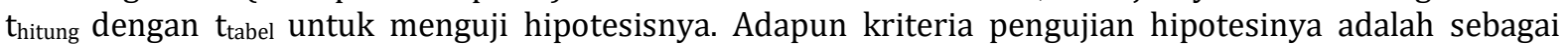
berikut:

Jika nilai thitung $>t_{\text {tabel }}$ maka signifikan $\left(\mathrm{H}_{\mathrm{a}}\right.$ diterima)

Jika nilai $t_{\text {hitung }}<t_{\text {tabel }}$ maka tidak signifikan $\left(\mathrm{H}_{0}\right.$ ditolak)

Berikut hipotesis yang dinatakan dalam bentuk kalimat:

$\mathrm{H}_{\mathrm{a}}$ : Terdapat hubungan antara penerapan penilaian autentik mata pelajaran PAI dan budi pekerti dengan prestasi belajar peserta didik.

$\mathrm{H}_{0}$ : Tidak terdapat hubungan antara penerapan penilaian autentik mata pelajaran PAI dan bu di pekerti dengan prestasi belajar peserta didik.

Berdasarkan data yang telah dipaparkan di atas, maka dapat disimpulkan bahwa $t_{\text {hitung }}>t_{\text {tabel }}$ dengan angka 2.076> 1.697, berarti $\mathbf{H}_{\mathbf{a}}$ diterima $\mathbf{H}_{0}$ ditolak.

Dengan demikian maka pernyataan dapat ditulis bahwa, $>$ (2.076> 1.697). Dari data trsebut dapat disimpulkan diterima dan ditolak. Karena itu hipotesis penelitian menyatakan terdapat hubungan positif antar variabel penilaian autentik (X) dengan prestasi belajar (Y).

\section{Pembahasan Hasil Penelitian}

Penelitian ini bertujuan untuk mengetahui hubungan penilaian autentik mata pelajaran PAI dan budi pekerti dengan prestasi belajar di SMAN Simpang Rimba Kab. Bangka Belitung. Berdasarkan hasil angket dari 25 item pernyataan, terdapat 20 item pernyataan yang valid. Sedangkan 5 item pernyataan lainnya ternyata nilai $r_{\text {hitung }}$ kurang dari nilai $r_{\text {tabel }}(0,374)$. Untuk mengukur tingkat kepercayaan atau reliabilitas instrumen angket variabel penilaian autentik (X) menggunakan teknik Spearmen Borwn (Split Half), reliabilitas dari data hasil instrumen peneliti dinyatakan reliabel atau konsisten. Karena hasil perhitungan reliabilitas instrumen peneliti lebih tinggi dari $r_{\text {tabel }}(0,374)$.

Proses untuk memperoleh deskripsi angka (skor) dengan setiap jawaban yang terendah "1" sedangkan jawaban yang tertinggi "4". Setelah keseluruhan soal yang disediakan dijawab oleh responden, langsung dihitung berapa jumlah skornya secara keseluruhan dari 33 peserta didik yang menjadi sampel penelitian.

Sebelum uji hipotesis dilakukan, uji asumsi dasar yang digunakan untuk mengetahui apakah analisis yang digunakan sudah memenuhi prasyarat atau asumsi yang berlaku atau tidak. Uji asumsi dasar dalam penelitian ini yaitu dengan uji normalitas menggunakan Kolmogorov-Smirnov. Uji normalitas digunakan apakah data berdistribusi normal atau tidak. 
Berdasarkan perhitungan uji normalitas menggunakan Kolmogorov-Smirnov dengan bantuan program SPSS versi 17.0, diketahui bahwa data penilaian autentik sebesar 0.168 dan prestasi belajar seberar 0.080 memiliki nilai signifikansi. Karena signifikansi kedua data tersebut lebih besar dari 0,05 jadi data penilaian autentik dan prestasi belajar dinyatakan berdistribusi normal.

Setelah melakukan uji normalitas data, maka dilakukan analisis Correlation Pearson Product Moment. Berdasarkan teori dan hasil pengujian yang telah diuraikan sebelumnya, maka hubungan penilaian autentik dengan prestasi belajar yaitusignifikan. Bahwa hasil Correlationvariabel X dan variabel Y sebesar $\mathbf{0 . 3 7 7}$.

Sedangkan untuk menguji hipotesisnya yaitu dapat membandingkan nilai $t_{\text {hitung }}$ dengan nilai tabel. Setelah didapati nilai thitung sebesar 2.076, berdasarkan data yang telah dipaparkan di atas, maka dapat disimpulkan bahwa thitung $>t_{\text {tabel }}$ dengan angka 2.076>1.697, berarti $\mathbf{H}_{\mathbf{a}}$ diterima $\mathbf{H}_{\mathbf{0}}$ ditolak. Namun bisa kita lihat bahwa hasil Correlations variabel X dan variabel Y. Nilai yang diperoleh sebesar 0, 377 berarti terdapat hubungan yang rendah antar penilaian autentik dan prestasi belajar. Ini berarti bahwa korelasi penilaian autentik mata pelajaran PAI dan budi pekerti denganprestasi belajar peserta didik di SMAN 1 Simpang Rimba Kab. Bangka Selatan menunjukan korelasi yang rendah..

\section{KESIMPULAN}

Berdasarkan hasil penelitian dan pembahasan tentang korelasi penerapan penilaian autentik dengan prestasi belajar di SMAN 1 Simpang Rimba Kab. Bangka Selatan, dapat disimpulkan:

Berdasarkan perhitungan uji normalitas menggunakan Kolmogorov-Smirnov, diketahui bahwa data penilaian autentik sebesar 0.168 dan prestasi belajar seberar 0.080 memiliki nilai signifikansi. Karena signifikansi kedua data tersebut lebih besar dari 0,05 jadi data penilaian autentik dan prestasi belajar dinyatakan berdistribusi normal.

Setelah melakukan uji normalitas data, maka dilakukan analisis Correlation Pearson Product Moment. Berdasarkan teori dan hasil pengujian yang telah diuraikan sebelumnya, maka hubungan penilaian autentik dengan prestasi belajar yaitu signifikan. Bahwa hasil Correlationvariabel X dan variabel $\mathrm{Y}$ sebesar 0.377 .

Sedangkan untuk menguji hipotesisnya yaitu dapat membandingkan nilai thitung dengan nilai tabel. Setelah didapati nilai thitung sebesar 2.076, berdasarkan data yang telah dipaparkan di atas, maka dapat disimpulkan bahwa thitung $>$ tabel dengan angka 2.076> 1.697, berarti $\mathbf{H}_{\mathbf{a}}$ diterima $\mathrm{H}_{0}$ ditolak. Namun bisa kita lihat bahwa hasil Correlations variabel X dan variabel Y. Nilai yang diperoleh sebesar $\mathbf{0 , 3 7 7}$ berarti terdapat hubungan yang rendah antar penilaian autentik dan prestasi belajar. Ini berarti bahwa korelasi penilaian autentik mata pelajaran PAI dan budi pekerti dengan prestasi belajar peserta didik di SMAN 1 Simpang Rimba Kab. Bangka Selatan menunjukan korelasi yang rendah.

\section{REFERENSI}

Andang. 2014.Manajemen dan Kepemimpinan Kepala Sekolah. Yogyakarta: Ar-Ruzz Media.

Arifin, Zainal. 2012.Penelitian Pendidikan. Bandung: PT Remaja Rosdakarya.

Astriyandi, Ari, Umi Chotimah, dkk. 2016. Kemampuan Guru Menerapkan Penilaian Autentik dalam Pembelajaran PPkn. Jurnal Bhinneka Tunggal Ika, Volume 3, Nomor 2.

Basuki, Ismet dan Hariyanto. 2016.Asesmen Pembelajaran. Bandung; PT Remaja Rosdakarya.

Bungin, Burhan. 2013.Metodologi Penelitian Kuantitatif: Komunikasi Ekonomi Kebijakan Publik Serta Ilmu-Ilmu Sosial Lainnya. Jakarta:Kencana.

Darmadi, Hamid. 2011. Metode Penelitian Pendidikan. Bandung: Alfabeta.

Fathurrohman, Muhammad, dan Sulistyorini. 2012. Belajar dan Pembelajaran Membantu Meningkatkankan Mutu Pembelajaran sesuai Standar Nasional. Yogyakarta: Teras.

Fadlillah, M. 2014. Implementasi Kurikulum 2013 dalam Pembelajaran SD/MI, SMP/MTs, \& SMA/MA. Yogyakarta: AR-RUZZ Media.

Kurinasih, Imas dan Berlin Sani. 2014.Implementasi Kurikulum 2013 Konsep dan Penerapan. Surabaya: Kata Pena . 2016.Revisi Kurikulum 2013 Implementasi konsep dan penerapan. Surabaya: Kata Pena.

Kunandar. 2010. Guru Profesional Implementasi Kurikulum Tingkat Satuan Pendidikan (KTSP) dan Sukses dalam Sertifikasi Guru. Jakarta: Raja Grafindo Persada. 2015. Penilaian Autentik (penilaian hasil belajar peserta didik berdasarkan kurikulum 2013) suatu pendekatan praktis disertai dengan contoh. Jakarta: Raja Grafindo Persada.

N, Sudirman. 1990. Ilmu Pendidikan, (Bandung: Remaja Rosdakarya. 
Permendikbud No. 69 Tahun 2013 tentang Kerangka Dasar dan Struktur Kurikulum Sekolah Menengah Atas / Madrasah Aliyah.

Riduwan. 2007. Skala Pengukur Variabel-Variabel Penelitian. Bandung: Alfabeta. 2009. Dasar-Dasar Statistika. Bandung: Alfabeta . 2013. Belajar Mudah Penelitian untuk Guru-Karyawan dan Peneliti Pemula. Bandung: Alfabeta.

Rifa'i, Veithzal. 2003.Upaya-Upaya Meningkatkan Hasil Belajar Kepemimpinan Peserta Diklat Spama Survei di Diklat Depkes. Jurnal Pendidikan dan Kebudayaan N0. 40, tahun ke-9, jakarta: Depdiknas.

Rumengan, Jemmy. 2015. Aplikasi Statistik dalam Penelitian Kuantitatif. Bandung: Citapustaka Media. Sabri, Alisuf. 1996.Psikologi Pendidikan. Jakarta: Pedoman Ilmu Jaya.

Sudijono, Anas. 2015. Pengantar Statistik Pendidikan. Jakarta: PT Raja Grafindo Persada.

Sugihartono, dkk. 2007.Psikologi Pendidikan. Yogyakarta: UNY Press.

Sugiyono. 2014.Metode Penelitian Pendekatan Kuantitatif, Kualitatif, dan R\&D. Bandung: Alfabeta.

Sugiyono dan Eri Wibowo. 2004.Statistika untu Penelitian. Bandung: Alfabeta.

Supriyono. 1991.Perlu Motivasi Instrinsik yang Kuat untuk Meraih Prestasi Belajar. Jakarta:Media. 